\title{
Hypovitaminosis D in pregnancy and its correlation with preeclampsia and gestational diabetes mellitus
}

\author{
Ankita Kumari ${ }^{1 *}$, Shaila Mitra ${ }^{2}$, Harish C. Tiwari ${ }^{3}$, Reena Srivastav ${ }^{1}$
}

\begin{abstract}
${ }^{1}$ Department of Obstetrics and Gynecology, Baba Raghav Das Medical College, Gorakhpur, Uttar Pradesh, India ${ }^{2}$ Department of Pathology, Baba Raghav Das Medical College, Gorakhpur, Uttar Pradesh, India

${ }^{3}$ Department of Community Medicine, Baba Raghav Das Medical College, Gorakhpur, Uttar Pradesh, India
\end{abstract}

Received: 29 January 2017

Revised: 02 February 2017

Accepted: 06 February 2017

\section{*Correspondence:}

Dr. Ankita Kumari,

E-mail: drankita09@gmail.com

Copyright: ( ) the author(s), publisher and licensee Medip Academy. This is an open-access article distributed under the terms of the Creative Commons Attribution Non-Commercial License, which permits unrestricted non-commercial use, distribution, and reproduction in any medium, provided the original work is properly cited.

\section{ABSTRACT}

Background: Hypovitaminosis D has been associated with a number of adverse pregnancy outcomes, and has been recognised as a public health concern. The objective of this study was to determine the impact of Vitamin D deficiency on maternal complications like gestational diabetes mellitus (GDM) and preeclampsia (PE) among pregnant women.

Methods: This was a case control study undertaken at antenatal clinics and indoor of BRD Medical College, Gorakhpur, Uttar Pradesh, India. Two maternal blood samples, one at $<20$ weeks and other at term along with cord blood at delivery were taken. Patients were classified into preeclampsia $(n=60)$, gestational diabetes mellitus $(n=35)$ and control group $(\mathrm{n}=180)$ after abstracting past medical records at delivery. Vitamin D was estimated by 25 Hydroxyvitamin D125 RIA kit and categorized according to ACOG criteria. Statistical analysis was done by using chi square test, binary logistic regression and Pearson's correlation coefficient to compare between two variables. $\mathrm{P}<0.05$ was considered statistically significant.

Results: Out of 275 women included in the study, $78 \%$ of women were Vitamin D deficient. Mean serum vitamin D was significantly lower among preeclamptic women $11.53 \pm 6.22 \mathrm{ng} / \mathrm{ml}$ and GDM women $12.62 \pm 6.69 \mathrm{ng} / \mathrm{ml}$ as compared to controls $24.25 \pm 14.44 \mathrm{ng} / \mathrm{ml}$ (median=18.2 ng/ml) $(\mathrm{P}<0.05)$. Vitamin D deficiency was significantly higher in pregnant women GDM $(94.28 \%$ vs $68.3 \%)$ and preeclampsia $(96.67 \%$ vs $68.3 \%)$ when compared to uncomplicated group.

Conclusions: Maternal vitamin D deficiency is highly prevalent in early pregnancy and is significantly associated with elevated risk for GDM and preeclampsia.

Keywords: Gestational diabetes mellitus, Preeclampsia, Vitamin D deficiency

\section{INTRODUCTION}

Vitamin D has been traditionally known as anti ricketic factor or sunshine factor. A decade ago identified as bone building mineral improving calcium absorption, today new research potentials of Vitamin D in spectrum of diseases from diabetes, hypertension to cancer including special population like pregnancy and lactation. Preeclampsia is a pregnancy specific syndrome characterized by hypertension and proteinuria, affecting approximately $2-10 \%$ of pregnancies and is the major cause of maternal and foetal morbidity and mortality worldwide, WHO estimates the incidence of preeclampsia to be seven times higher in developing countries $(2.8 \%$ of live births) than in developed countries $(0.4 \%){ }^{1-4}$ It contributes to major proportions of maternal deaths, upto $16 \%$ in developed countries. ${ }^{5}$ Various risk factors and preventive methods have been 
tested. ${ }^{1}$ Still there are no definite preventive measures. Pathogenesis of preeclampsia is believed to involve maternal immune rejection of the placental cytotrophoblast leading to inadequate remodelling and trophoblastic invasion of spiral arteries leading to shallow implantation and hypoxia and release of inflammatory mediators. ${ }^{6}$ With the recognition of immunomodulatory properties of vitamin $\mathrm{D}$, the role of this secosteroid hormone in normal placentation had been the subject of recent research. Vitamin D receptors ${ }^{7}$ and $1 \alpha$ hydroxylase are expressed both in decidua and trophoblast cells, providing an evidence for role of vitamin $\mathrm{D}$ in placentation. $^{8}$

Gestational diabetes mellitus (GDM) and impaired glucose tolerance (IGT) affect maternal, foetal and neonatal well-being. The prevalence of GDM is increasing globally. It has been estimated that the total prevalence of GDM reaches almost $15 \%-20 \% .^{9}$ In mother, GDM is associated with higher risk of caesarean section and later development of Type 2 diabetes. For offspring, GDM is associated with macrosomia, birth trauma, respiratory distress syndrome, jaundice and hypoglycaemia. ${ }^{10}$ Moreover, their offspring are prone to develop childhood obesity and T2DM later in life. ${ }^{11}$ The well-established risk factors for GDM include high maternal age, obesity or maternal overweight status, prior history of GDM, family history of T2DM and so, on. ${ }^{10,11}$ However, it is not clear whether a poor vitamin D status is associated with risk of GDM.

There is paucity of literature pertaining to association between hypovitaminosis D and preeclampsia as well gestational diabetes mellitus from sunrich country of India. So, this study was conducted to find the correlation of vitamin D deficiency with preeclampsia and gestational diabetes mellitus.

\section{METHODS}

This case control study was conducted over a period of 24 months in tertiary care hospital of Eastern Uttar Pradesh, India. A total number of 375 antenatal women were enrolled in the study at less than 20 weeks gestation from antenatal outpatient clinics of BRD Medical College, Gorakhpur. Women coming later in pregnancy i.e. $>20$ weeks were not taken into account.

Inclusion criteria were all antenatal women less than 45 years of age with live, singleton pregnancy. Women with pre-existing medical conditions like diabetes mellitus (Type I and II), chronic hypertension, rheumatoid arthritis, thyroid, lupus, malabsorption, or with multiple pregnancy, or with gastric bypass surgery or history of intake of medications influencing bone, vitamin $\mathrm{D}$ or calcium metabolism e.g. antiepileptic/ theophylline/ antitubercular drugs in the last 6 months were excluded. Written informed consent was obtained from all the women. Relevant details like age, gravidity, education, occupation and socio-demographic factors were noted on a predesigned performa.

Blood sample for vitamin D level was collected aseptically by venepuncture in a $5 \mathrm{ml}$ evacuated glass tube at the time of enrolment and immediately transported to laboratory. Serum was separated by centrifugation and stored at $-20^{\circ} \mathrm{C}$ for evaluation at later stage. Subjects were followed in second and third trimester and at delivery maternal blood and cord blood samples were collected. Serum from these samples were similarly extracted and stored at $-20^{\circ} \mathrm{C}$. After delivery, medical records were abstracted to ascertain blood pressures, and urinary protein measurement throughout gestation, use of antihypertensive medications, antepartum and delivery events, family H/O DM, H/O chronic renal disease, and glucose tolerance test (GTT) and neonatal outcomes.

At this point antenatal women were categorized into preeclampsia (PE) group, gestational diabetes mellitus (GDM) group and control group. Preeclamptic cases had to meet the American College of Obstetrics and Gynaecology criteria for diagnosing pre-eclampsia. ${ }^{12}$ Similarly, GDM cases had to meet the American Diabetes Association criteria to be diagnosed as Gestational diabetes mellitus. ${ }^{13}$ Banked serum samples of each group i.e. pre-eclampsia, GDM and control group were taken out and subjected to RIA $25 \mathrm{OH}$ vitamin D estimation. The study was approved by medical ethics committee BRD Medical College, Gorakhpur, Uttar Pradesh, India.

Among total of 375 women enrolled in the study, 46 were lost in the second trimester, 22 lost in third trimester, 10 had delivery in other hospital. 12 of subjects had preterm delivery before 32 weeks, 7 samples were contaminated and 3 samples were haemolysed. Only 275 subjects had complete serum samples i.e. one sample before 20 weeks, one at delivery and one cord blood serum sample. Therefore, out of 275 antenatal women there were 60 preeclampsia, 35 GDM and 180 served as control.

\section{Measurement of vitamin D}

Quantitation of serum 25(OH) Vitamin $\mathrm{D}\left[25(\mathrm{OH}) \mathrm{D}_{2}+25(\mathrm{OH}) \mathrm{D}_{3}\right]$ was performed using a commercial ELISA from immunodiagnostic systems limited in the pathology laboratory of BRDMC. The ELISA could detect $25(\mathrm{OH})$ vitamin $\mathrm{D}$ in the range of 2 $120 \mathrm{ng} / \mathrm{ml}$. This assay can detect $25(\mathrm{OH}) \mathrm{D}_{3}$ concentration as low as $1.28 \mathrm{ng} / \mathrm{ml}$. None of the samples in our analysis fell below the detectable range. The inter assay coefficient of variation of ELISA was $10.3 \%$. The ELISA recognised $100 \%$ of $25(\mathrm{OH})$ vitamin $\mathrm{D}_{3}$ and $75 \%$ of $25(\mathrm{OH})$ vitamin $\mathrm{D}_{2}$ but did not distinguish between these two forms.

Deficiency was defined as level of $<20 \mathrm{ng} / \mathrm{ml}$, insufficiency as $20-30 \mathrm{ng} / \mathrm{ml}$ and optimal level as $>30$ 
ng/ml [ACOG 2011]. ${ }^{14}$ However, in neonates vitamin D status was classified according to Drug and Therapeutics Committee of Lawsons Wilkins Pediatric Endocrine Society (LWEPS) recommendations i.e. $<5 \mathrm{ng} / \mathrm{ml}$ severe deficiency, 5-15 $\mathrm{ng} / \mathrm{ml}$ deficiency, $15-20 \mathrm{ng} / \mathrm{ml}$ insufficiency, and 20-100 ng/ml sufficiency. ${ }^{15-17}$ The data was analysed using SPSS version 17.

Statistical analysis used chi square test, binary logistic regression, Pearson's correlation coefficient to compare between two variables. A p value $<0.05$ was considered significant.

\section{RESULTS}

The prevalence of Vitamin D deficiency (Vitamin D $<20$ $\mathrm{ng} / \mathrm{ml}$ ) in entire study population at early gestation and at term was found to be $77.8 \%$ (214 out of 275 ) vs $77.1 \%$ (212 out of 275) (Figure 1).

Table 1: Sociodemographic characteristics.

\begin{tabular}{|c|c|c|c|}
\hline Maternal characteristics & Preeclampsia (\%) & GDM (\%) & Control (\%) \\
\hline \multicolumn{4}{|l|}{ Age (years) } \\
\hline$<20$ & $2(3.33 \%)$ & $00(0.0 \%)$ & $10(5.56 \%)$ \\
\hline $20-30$ & $37(61.67 \%)$ & $19(54.28 \%)$ & $121(67.22 \%)$ \\
\hline $30-40$ & $19(31.67 \%)$ & $15(42.86 \%)$ & $44(24.44 \%)$ \\
\hline$>40$ & $02(3.33 \%)$ & $01(2.86 \%)$ & $05(2.78 \%)$ \\
\hline $\mathrm{P}$ value & $<0.05$ & $>0.05$ & \\
\hline \multicolumn{4}{|l|}{ Relegion } \\
\hline Hindu & $42(70 \%)$ & $23(65.71 \%)$ & $116(64.44 \%)$ \\
\hline Muslims & $18(30 \%)$ & $12(34.28 \%)$ & $64(35.56 \%)$ \\
\hline Others & $00(0.0 \%)$ & $00(0.0 \%)$ & $01(0.56 \%)$ \\
\hline $\mathrm{P}$ value & $>0.05$ & $>0.05$ & \\
\hline \multicolumn{4}{|l|}{ Geographical region } \\
\hline Rural & $43(71.67 \%)$ & $25(71.43 \%)$ & $106(58.89 \%)$ \\
\hline Urban & $17(28.33 \%)$ & $10(28.57 \%)$ & $74(41.11 \%)$ \\
\hline $\mathrm{p}$ value & $>0.05$ & $>0.05$ & \\
\hline \multicolumn{4}{|l|}{ Education } \\
\hline Illiterate & $26(43.33 \%)$ & $14(40 \%)$ & $76(42.22 \%)$ \\
\hline Primary & $19(31.67 \%)$ & $12(34.28 \%)$ & $60(33.33 \%)$ \\
\hline Secondary & $11(18.33 \%)$ & $0720 \%)$ & $41(22.78 \%)$ \\
\hline Higher & $04(6.67)$ & $02(5.71 \%)$ & $03(1.67 \%)$ \\
\hline $\mathrm{p}$ value & $>0.05$ & $>0.05$ & \\
\hline \multicolumn{4}{|l|}{ Socioeconomic status } \\
\hline Class 1 & $01(1.67 \%)$ & $2(5.71 \%)$ & $03(1.67 \%)$ \\
\hline Class 2 & $24(40 \%)$ & $14(40 \%)$ & $57(31.67 \%)$ \\
\hline Class 3 & $20(33.33 \%)$ & $11(31.43 \%)$ & $83(46.11 \%)$ \\
\hline Class 4 & $11(18.33 \%)$ & $05(14.28 \%)$ & $28(15.56 \%)$ \\
\hline Class 5 & $04(6.67 \%)$ & $03(8.57 \%)$ & $09(5 \%)$ \\
\hline $\mathrm{p}$ value & $>0.05$ & $>0.05$ & \\
\hline \multicolumn{4}{|l|}{ Smoking } \\
\hline Smokers & $02(3.33 \%)$ & $00(0.0 \%)$ & $11(6.11 \%)$ \\
\hline Non Smokers & $58(96.67 \%)$ & $35(100 \%)$ & $169(93.89 \%)$ \\
\hline $\mathrm{p}$ value & $>0.05$ & $>\mathrm{NA}$ & \\
\hline \multicolumn{4}{|l|}{ Prepregnancy BMI $\left(\mathrm{kg} / \mathrm{m}^{2}\right)$} \\
\hline$<18.5$ & $01(1.67 \%)$ & $00(0.0 \%)$ & $03(1.67 \%)$ \\
\hline $18.5-24.9$ & $25(41.67 \%)$ & $10(28.57 \%)$ & $113(62.78 \%)$ \\
\hline $25-29.9$ & $32(53.33 \%)$ & $16(45.71 \%)$ & $61(33.70 \%)$ \\
\hline$\geq 30$ & $02(3.33 \%)$ & $09(25.71 \%)$ & $03(1.67 \%)$ \\
\hline $\mathrm{p}$ value & $<0.05$ & $<0.001$ & \\
\hline \multicolumn{4}{|l|}{ Gravidity } \\
\hline Primi & $41(68.33 \%)$ & $27(77.14 \%)$ & $70(38.89 \%)$ \\
\hline 2 & $12(20 \%)$ & $05(14.28 \%)$ & $58(32.22 \%)$ \\
\hline$\geq 3$ & $7(11.67 \%)$ & $03(8.57 \%)$ & $52(28.89 \%)$ \\
\hline $\mathrm{p}$ value & $<0.001$ & $<0.001$ & \\
\hline
\end{tabular}




\begin{tabular}{|llll|}
\hline Use of vitamin D suppliments & & & \\
\hline Yes & $11(18.33 \%)$ & $09(25.71 \%)$ & $59(32.78 \%)$ \\
\hline No & $49(81.67 \%)$ & $26(74.28 \%)$ & $121(67.22 \%)$ \\
\hline p value & $<0.05$ & $>0.05$ & \\
\hline Sun exposure & & & \\
\hline Adequate & $21(35 \%)$ & $13(37.14 \%)$ & $78(43.33 \%)$ \\
\hline Inadequate & $39(65 \%)$ & $22(62.86 \%)$ & $102(56.67 \%)$ \\
\hline p value & $>0.05$ & $>0.05$ & \\
\hline Dietary habits & & & \\
\hline Veg & $56(93.33 \%)$ & $32(91.43 \%)$ & $123(68.33 \%)$ \\
\hline Non veg & $4(6.67 \%)$ & $03(8.57 \%)$ & $57(31.67 \%)$ \\
\hline p value & $<0.001$ & $<0.05$ & \\
\hline Seasons & & & \\
\hline Summer & $7(11.67 \%)$ & $25(71.43 \%)$ & $26(14.44 \%)$ \\
\hline Autumn & $00(0.0)$ & $2(5.71 \%)$ & $21(11.67 \%)$ \\
\hline Spring & $14(23.33 \%)$ & $2(5.71 \%)$ & $69(38.33 \%)$ \\
\hline Winter & $39(65 \%)$ & $06(17.14 \%)$ & $64(35.56 \%)$ \\
\hline p value & $<0.05$ & $>0.05$ & \\
\hline
\end{tabular}

Preeclamptic as well as GDM cases were primarily found in the age group of $25-29$ years (mean age $=28 \pm 5.8$ years and $26.4 \pm 4.55$ years in PE and GDM respectively). No statistically significant differences were found in religion, residence, educational status and smoking habits among the groups. Most of the women in preeclampsia as well as GDM were overweight, had low level of physical activity in sun and less use of periconceptional multivitamin from beginning of pregnancy. Majority of preeclampsia cases occurred in winters while that of GDM occurred in summer season (Table 1). Inadequate sun exposure $(\mathrm{OR}=2.096, \mathrm{P} \leq 0.05)$, vegetarian $\operatorname{diet}(\mathrm{OR}=0.123, \mathrm{P} \leq 0.05)$ and winter season $(\mathrm{OR}=1.655, \mathrm{P} \leq 0.05)$ were important risk factors as revealed by binary logistic regression. Inclusion of other risk factors like BMI, socioeconomic status, residence, age, periconceptional multivitamin use etc. hardly change overall $25(\mathrm{OH}) \mathrm{D}$ concentration in the study.

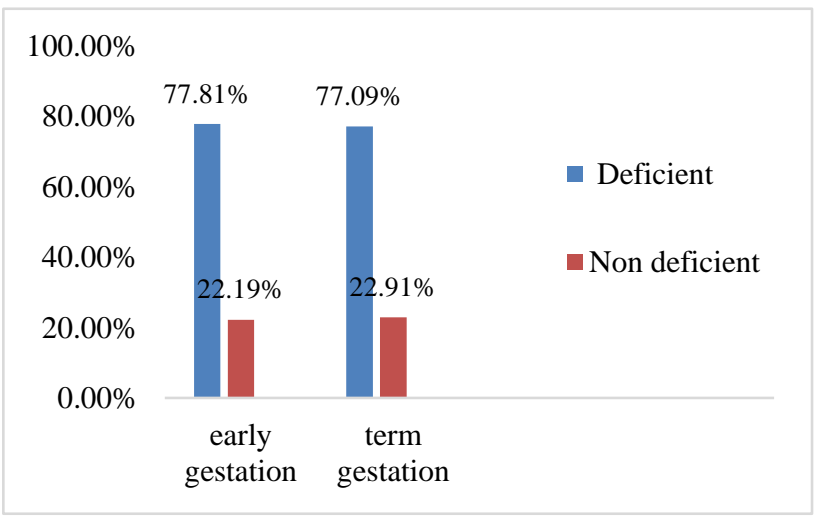

Figure 1: Prevalence of vitamin D deficiency in entire study population.

Although vitamin D status does not depend on severity of pre eclampsia but severe preeclamptic patients had more severe deficiency of vitamin D. Majority of these patients (77.27\%) had very low vitamin D concentration (Figure 2). Early pregnancy maternal $25(\mathrm{OH}) \mathrm{D}$ concentration less than $20 \mathrm{ng} / \mathrm{ml}$ was significantly associated with the risk of preeclampsia $(\mathrm{p}<0.001)$, independent of age, prepregnancy BMI, education, gravidity, socioeconomic status, residence and religion. Vitamin D deficiency was significantly associated with GDM when compared with control (Table 2). We also found that $25(\mathrm{OH}) \mathrm{D}$ level at $<20$ weeks gestation had a significant negative correlation with systolic blood pressure $(\mathrm{r}=-0.5326$, $\mathrm{p}<0.0001)$ and diastolic blood pressure $(\mathrm{r}=-0.5140$, $\mathrm{p}<0.0001$ ) (Table 5).

Table 2: Association of maternal vitamin D status at $<20$ weeks of gestation with preeclampsia and GDM.

\begin{tabular}{|llll|}
\hline $\begin{array}{l}\text { Vitamin } \\
\text { D level at } \\
<20 \\
\text { weeks } \\
(\mathrm{ng} / \mathrm{ml})\end{array}$ & $\begin{array}{l}\text { Preeclampsia } \\
\text { group (\%) }\end{array}$ & $\begin{array}{l}\text { GDM group } \\
(\%)\end{array}$ & $\begin{array}{l}\text { Control } \\
\text { Group } \\
(\%)\end{array}$ \\
\hline$<20$ & $\begin{array}{l}58 \\
(96.67 \%)\end{array}$ & $\begin{array}{l}33 \\
(94.28 \%)\end{array}$ & $\begin{array}{l}123 \\
(68.33 \%)\end{array}$ \\
\hline $20-29$ & $\begin{array}{l}1 \\
(1.67 \%)\end{array}$ & $\begin{array}{l}02 \\
(5.71 \%)\end{array}$ & $\begin{array}{l}18 \\
(10 \%)\end{array}$ \\
\hline$\geq 30$ & 1 & 00 & 39 \\
& $(1.67 \%)$ & $(0.0 \%)$ & $(21.67 \%)$ \\
\hline Total & 60 & 35 & 180 \\
$(100 \%)$ & $(100 \%)$ & $(100 \%)$ \\
\hline p value & $<0.001$ & $<0.05$ & \\
\hline $\begin{array}{l}\text { Note: } \mathrm{p} \text { value } \\
\text { with control. }\end{array}$ & & &
\end{tabular}

At term, hypovitaminosis D was significantly associated with the risk of preeclampsia $(\mathrm{p}<0.05)$ as well as gestational diabetes mellitus $(\mathrm{p}<0.05)$ (Table 3$)$. Serum vitamin $\mathrm{D}$ concentration at term had a significant 
negative correlation with fasting blood glucose while no correlation with post prandial blood glucose (Table 6). Also, there was a significant negative correlation between $25(\mathrm{OH}) \mathrm{D}$ concentration at term and systolic blood pressure $(\mathrm{r}=-0.5024, \mathrm{p}<0.0001)$ and diastolic blood pressure $(r=-0.4408, \mathrm{p}<0.005)$ respectively (Table 5).

Table 3: Association of maternal vitamin D status at term gestation with preeclampsia and GDM.

\begin{tabular}{|llll|}
\hline $\begin{array}{l}\text { Vitamin D } \\
\text { level at term } \\
\text { gestation } \\
(\text { ng/ml) }\end{array}$ & $\begin{array}{l}\text { Preeclampsia } \\
\text { group (\%) }\end{array}$ & $\begin{array}{l}\text { GDM } \\
\text { group (\%) }\end{array}$ & $\begin{array}{l}\text { Control } \\
(\%)\end{array}$ \\
\hline$<20$ & 56 & 32 & 124 \\
& $(93.33 \%)$ & $(91.43 \%)$ & $(68.89 \%)$ \\
\hline $20-29$ & 3 & 1 & 20 \\
& $(5 \%)$ & $(2.86 \%)$ & $(11.11 \%)$ \\
\hline$\geq 30$ & $1(1.67 \%)$ & $2(5.71 \%)$ & $36(20 \%)$ \\
\hline Total & 60 & 35 & 180 \\
$(100 \%)$ & $(100 \%)$ & $(100 \%)$ \\
\hline p value & $<0.05$ & $<0.05$ & \\
\hline
\end{tabular}

Note: $p$ value $<0.05$ is considered significant when compared with control.

Table 4: Association of neonatal vitamin D status with preeclampsia and GDM.

\begin{tabular}{|llll|}
$\begin{array}{l}\text { Cord } \\
\text { serum } \\
\begin{array}{l}\text { Vit D } \\
(\mathrm{ng} / \mathrm{ml})\end{array}\end{array}$ & $\begin{array}{l}\text { Neonates of } \\
\text { preeclamptic } \\
\text { mother }(\%)\end{array}$ & $\begin{array}{l}\text { Neonates of } \\
\text { GDM } \\
\text { mothers } \\
(\%)\end{array}$ & $\begin{array}{l}\text { Neonates of } \\
\text { Control } \\
\text { mothers } \\
(\%)\end{array}$ \\
\hline$<15$ & $51(85 \%)$ & $30(85.71 \%)$ & $108(60 \%)$ \\
\hline $15-20$ & $05(8.3 \%)$ & $3(8.57 \%)$ & $35(19.44 \%)$ \\
\hline$>20$ & $04(6.67 \%)$ & $2(5.71 \%)$ & $37(20.55 \%)$ \\
\hline Total & $60(100 \%)$ & $35(100 \%)$ & $180(100 \%)$ \\
\hline p value & $<0.05$ & $<0.05$ & \\
\hline
\end{tabular}

Note: $\mathrm{p}$ value $<0.05$ is considered significant when compared with control.

Table 5: Correlation of preeclampsia with vitamin D level at $<20$ weeks, at term pregnancy and their cord blood levels.

\begin{tabular}{|lllll|}
\hline $\begin{array}{l}\text { Blood } \\
\text { pressure }\end{array}$ & & $\begin{array}{l}25(\mathrm{OH}) \mathrm{D} \text { at } \\
<20 \text { weeks }\end{array}$ & $\begin{array}{c}25(\mathrm{OH}) \mathrm{D} \\
\text { at term }\end{array}$ & $\begin{array}{l}\text { 25(OH }) \mathrm{D} \\
\text { of cord } \\
\text { blood }\end{array}$ \\
\hline $\begin{array}{l}\text { Systolic } \\
\begin{array}{l}\text { BP at } \\
\text { term }\end{array}\end{array}$ & $\mathrm{r}$ & -0.5326 & -0.5024 & -0.3610 \\
\hline $\begin{array}{l}\text { Diastolic } \\
\text { BP at }\end{array}$ & $\mathrm{r}$ & -0.5140 & -0.4408 & -0.3259 \\
term & $\mathrm{p}$ & $<0.0001$ & 0.0005 & 0.0126 \\
\hline
\end{tabular}

Note: $r=$ pearson's correlation coefficient, $p=p$ value.

Among preeclampsia cases who were deficient in $25(\mathrm{OH}) \mathrm{D}$ concentration level, $85 \%$ of neonates had deficient cord blood of $25(\mathrm{OH}) \mathrm{D}$ concentration. However, $85.7 \%$ of neonates of GDM mothers were deficient in cord blood $25(\mathrm{OH}) \mathrm{D}$ concentration. This can be explained by the known value of vitamin $\mathrm{D}$ at $<20$ weeks (Table 4). Women with gestational diabetes mellitus and their newborns had a higher frequency of $25(\mathrm{OH}) \mathrm{D}$ deficiency than control. The deficiencies of Vitamin D status between GDM women and control was significant $(\mathrm{p}<0.05)$ as well as between their newborns $(\mathrm{p}<0.05)$.

Table 6: Correlation of GDM with vitamin D level at $<20$ weeks, at term pregnancy and their cord blood levels.

\begin{tabular}{|lllll|}
\hline $\begin{array}{l}\text { Blood } \\
\text { sugar }\end{array}$ & $\begin{array}{l}25(\mathrm{OH}) \mathrm{D} \text { at } \\
<20 \text { weeks }\end{array}$ & $\begin{array}{l}25(\mathrm{OH}) \mathrm{D} \text { at } \\
\text { Term }\end{array}$ & $\begin{array}{l}25(\mathrm{OH}) \mathrm{D} \text { in } \\
\text { neonatal } \\
\text { cord blood }\end{array}$ \\
\begin{tabular}{|l} 
FBS \\
at
\end{tabular} & $\mathrm{r}$ & -0.3694 & -0.3542 & -0.2740 \\
Term & $\mathrm{p}$ & $<0.05$ & $<0.05$ & $0.1228(\mathrm{NS})$ \\
\hline $\begin{array}{l}\text { PPBS } \\
\text { at }\end{array}$ & $\mathrm{r}$ & -0.1871 & -0.2931 & -0.2208 \\
Term & $\mathrm{p}$ & $0.1597(\mathrm{NS})$ & $0.0978(\mathrm{NS})$ & $0.2170(\mathrm{NS})$ \\
\hline
\end{tabular}

Note: $r=$ pearson's correlation coefficient, $p=p$ value.

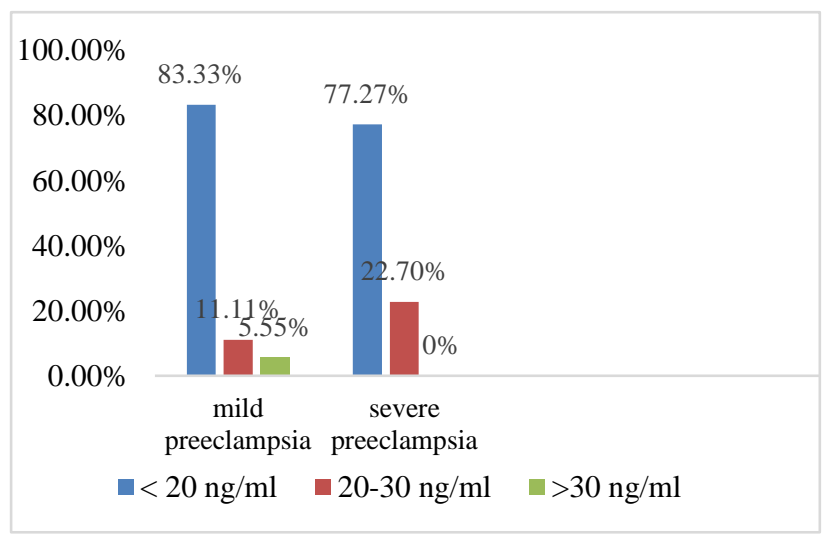

Figure 2: Relationship of vitamin D status with severity of preeclampsia.

\section{DISCUSSION}

We have found a high prevalence of Vitamin D deficiency $(77.81 \%$ ) in early pregnancy in a tropical country like India which has abundant sunlight for most of the year. This paradox can be explained due to many prevalent social and cultural practices along with increased urbanisation, poor outdoor activity and greater pollution.

The mean vitamin $\mathrm{D}$ concentration at term was found to be $11.53 \pm 6.22,12.62 \pm 6.69$ and $24.25 \pm 14.22$ (median 18.2) in pregnant women with preeclampsia, GDM and uncomplicated group respectively. It was reported that vitamin D status in women with risk factors of maternal complications like GDM and preeclampsia was significantly lower compared with women without risk factors. ${ }^{18}$ 
In present study, primigravida women and those with increased BMI were significantly associated with preeclampsia and GDM. A study done in Saudi Arabia showed that women at extremes of maternal age, the nulliparous women and high parity women are at an increased risk of developing preeclampsia. The variation in present study with other studies could be due to the differences in the population based and hospital based study. ${ }^{19}$ The finding that obese women are at the higher risk of preeclampsia and GDM is similar to the studies which showed obesity is a risk factor for preeclampsia and GDM, but the mechanism involved are not known. ${ }^{20-}$ 25 Women with the low BMI are relatively protected against preeclampsia, which is also confirmed in present study. ${ }^{26}$ In the current study the dietary intake of vitamin D was almost same in all the three groups. In a relatively large prospective study performed in Norway by Haugen et al, the risk of PE was found to be decreased by $27 \%$ in patients who received vitamin $D$ in a dose of $400-600$ IU/ day through supplement treatment. ${ }^{27}$

In the present study most of the GDM patients were found in summer season, however preeclampsia rates were elevated during winter month when sunlight dependent $25(\mathrm{OH}) \mathrm{D}$ production was reduced $(\mathrm{p}<0.05)$. This is similar to the study done by Ros $\mathrm{H} \mathrm{S}$ et $\mathrm{al}^{28}$ who found that the incidence of preeclampsia peaks during winter and is the lowest in summer and early autumn.

In the current study, although the vitamin D level did not depend on severity of preeclampsia but severe preeclamptic patients had more severe deficiency of vitamin D. Majority of these patients $(77.27 \%)$ had very low serum vitamin D concentration (Figure 2). This is comparable to the study done by Baker et al who found that mid gestation maternal $25(\mathrm{OH}) \mathrm{D}$ concentration was lower in women who subsequently developed severe preeclampsia compared with controls. ${ }^{29}$

The present study revealed a significant association between preeclampsia and vitamin D deficiency. Vitamin $\mathrm{D}$ deficiency was significantly higher in pregnant women with preeclampsia compared with the control group $(95.5 \%$ vs $68.7 \%$ ), which is consistent with a metaanalysis showing a significant association between 25(OH)D deficiency. ${ }^{30}$ However, no significant association was observed in a prospective cohort study of pregnancies at high risk for preeclampsia in Canada. ${ }^{31}$ The study result revealed that maternal vitamin $\mathrm{D}$ deficiency was a strong, independent risk factor for preeclampsia. Vitamin D deficiency also elevates blood pressure. There was a strong inverse relation between serum 25(OH)D levels at less than 20 weeks and high risk of preeclampsia( $\mathrm{r}=-0.5326, \mathrm{p}<0.0001)$. Moreover, there was a significant negative correlation between vitamin $\mathrm{D}$ level at term and in neonates and preeclampsia $(\mathrm{r}=-0.5024, \mathrm{p}<0.0001$ and $\mathrm{r}=-0.3610, \mathrm{p}<0.005)$. This is in accordance with the study performed by Bodnar et al and Zeghoud et al. ${ }^{32,33}$
Gestational diabetes is a result of pregnancy induced insulin resistance and impaired compensating insulin secretion. Vitamin D improves insulin sensitivity by enhancing insulin responsiveness to glucose transport. In our study, Vitamin D deficiency was significantly higher in pregnant women with GDM (96.9\%) than those without GDM (68.7\%), which is in line with findings from the cross sectional study of Maghbooli et al. ${ }^{34}$ This was in contrast to Ferrant et al, who studied 559 pregnant women in India and found no association between second trimester 25(OH)D levels and GDM. ${ }^{35}$ We noted a negative correlation between fasting blood glucose and vitamin D levels in our study. This is in corroboration with Tsur et al. ${ }^{36}$ Present results also highlight that neonates are at particularly high risk of vitamin D deficiency. However, these results are not unexpected. The foetus relies entirely on the Vitamin D stores of the mother, so if the mother is deficient, so is the fetus. ${ }^{37}$ Zeghoud et al stated that maternal vitamin $\mathrm{D}$ status correlates strongly with that of the newborn. ${ }^{33}$ The current study supports the hypothesis that Vitamin D deficiency is correlated with an increased risk of maternal complications as GDM and preeclampsia.

\section{CONCLUSION}

Vitamin D deficient pregnant women had less exposure to sunlight, no physical activity, and less Vitamin D supplement intake. At present, vitamin D supplementation is not a part of antenatal care programs in India. Vitamin D supplementation in early pregnancy may be a simple way to reduce the risk of these adverse pregnancy outcomes.

\section{ACKNOWLEDGEMENTS}

Authors are very thankful to Dr. Rajiv Kumar Mishra, Principal, BRD Medical College, Gorakhpur for assisting us in getting the investigations done free of cost without which this study could not have been possible

Funding: No funding sources

Conflict of interest: None declared

Ethical approval: The study was approved by the Institutional Ethics Committee of Baba Raghav Das Medical College, Gorakhpur, Uttar Pradesh, India

\section{REFERENCES}

1. Duckitt K, Harrington D. Risk factors for preeclampsia in antenatal booking: systematic review of controlled studies. BMJ. 2005;330: 565.

2. Guidotti R. Geographical variation in the incidence of hypertension in pregnancy. Am J Obstet Gynecol. 1988; $158: 80-3$.

3. Roberts CL, Ford JB, Algert CS, Antosen S, Chalmers $\mathrm{J}$, Cnattingires $\mathrm{S}$ et al. Population based trends in pregnancy hypertension and preeclampsia: an international comparative study. BMJ. 2011;1:1-9. 
4. Osungbade KO, Ige OK. Implications for health system strengthening. J Pregnancy. 2011;2011:1-6.

5. Khan KS, Wojdyla D, Say L, Gulmezoglu AM, Vanlook PFA. WHO analysis of causes of maternal death: a systematic review. Lancet. 2006;367:1066-74.

6. Evans KN, Bulmer JN, Kibly MD. Hewson M Vitamin $\mathrm{D}$ and placental decidual function. $\mathrm{J}$ soc Gynecol Investig. 2004;11:263-71.

7. Norman AV. Vitamin D receptor: new assignments for an already busy receptor. Endocrinol. 2006;147:5542-8.

8. Zhender D, Bland R, Williams MC, McNinch RW, Howie AJ, Stewart PM et al. Extrarenal expression of 25-hydroxy-vitamin d(3)-1 alpha hydrodylase. J Clin Endocrinol Metab. 2001;86:888-94.

9. American Diabetes Association. Standards of medical care in diabetes . Dia care. 2014;37(1):S14-S80.

10. Kjos SL, Buchanan TA. Gestational diabetes mellitus. N Eng J Med. 1999;341:1749.

11. Reece EA, Leguizamon G, Wiznitzer A. Gestational diabetes. The need for a common ground. Lancet. 2009;373,1789-97.

12. Diagnosis and management of preeclampsia and eclampsia. American College of Obstetricians and Gynecologists (ACOG) Practice bulletin. Obstet Gynecol. 2002;99(1):159-67.

13. Diagnosis and classification of Diabetes Mellitus. American Diabetes Association. Dia Care. 2014;37(1):S81-90.

14. Holick MF. Vitamin D deficiency. N Eng J Med. 2007;357:266-81.

15. Madhusmita M, Daniele P, Anna P, Paulo F, Michael K. Vitamin D deficiency in children and its management. On behalf of Drug and therapeutics committee of Lawsons Wilkins Endocrine society. Pediatrics. 2008;2:398-417.

16. Munns C, Zocharin MR, Roddo CP. Prevention and treatment of infant and childhood Vitamin D deficiency in Australia and New Zealand consensus statement. Med J Aust. 2006;185:268-72.

17. Gordan CMDPHA, Grace E, Emans SJ. Prevalance of Vitamin D deficiency among healthy adolescents. Arch Pediatr Adoles Mes. 2004;6:531-7.

18. Bener A, Al- Hamaq AOOA, Saleh NM. Association between vitamin $\mathrm{D}$ deficiency and adverse pregnancy outcome: global comparisons. Int $\mathrm{J}$ Wom Health. 2013;5:523-31

19. Lawoyn TO, Ani F. Epidemiological aspects of preeclampsia in Saudi Arabia. East Afr Med J. 1996;73:404-6.

20. Rosenberg TJ. Pre-pregnancy weight and adverse perinatal outcome in an ethnically diverse population. Obstet Gynecol. 2004,103:219-24.

21. Cedergerm MI. Maternal morbid obesity and the risk of adverse pregnancy outcome. Obstet Gynecol. 2004;103:219-24.

22. Weiss JL, Malone FD, Emig D, Ball RH, Nyberg DA, Comstock $\mathrm{CH}$, et al. Obesity, obstetric complications and caesarean delivery rate- a population based screening study. Am J Obstet Gynecol 2004; 190: 10911097.

23. Ramos GA, Caughly AB. The interrelationship between ethnicity and obesity on obstetric outcomes. Am J Obstet Gynecol 2005; 193: 1089- 1093.
24. Nohr EA et al. Prepregnancy and fetal death: a study within the Danish national birth cohort. Obstet Gynecol. 2005;106:250-9.

25. Bodnar LM, Ness RB, Harger GF, Roberts JM. Inflammation and triglycerides partially mediate the effect of prepregnancy body mass index on the result of preeclampsia. Am J Epidemiol. 2005;162:1198-206.

26. Belogolovkin V. The effect of low body mass index on the development of gestational hypertension and preeclampsia. J Matern Fetal Neonatal Med. 2007;20:509-13.

27. Haugen M, Brantsaeteo AL, Trogsted L, Alexander J, Roth C, Pand M, Meltzer HM. Vitamin D supplementation and reduced risk of preeclampsia in nulliparous women. Epidemiol (Cambridge mass). 2009;20(5):720-6.

28. Ros HS, Cnattingius S, Lipworth L. Comparison of risk factors for preeclampsia and gestation HTN in a population based cohort study. Am J Epidemiol. 1998;147:1062-70.

29. Baker AM, Haeri S, Camagro CA Jr, Stuebe AM. A nested case control study of mid gestation vitamin D deficiency increases the risk of preeclampsia. J Clin Endocrinol Metab. 2010;95:5105-9.

30. Robinsons CJ, Alanis MC, Wagner CL, Hollis BW, Johnson DD. Plasma 25 hydroxyvitamin D levels in early onset severe preeclampsia. Am J Obstet Gynecol. 2010;203:366-e1-e6.

31. Shand AW, Nassar N, Von Dadelszen P, Innis SM, Green TJ. Maternal vitamin D status in pregnancy and adverse pregnancy outcomes in a group at high risk for preeclampsia. BJOG. 2010;117:1593-8.

32. Bodnar LM, Catov JM, Simhan HN, Holick MF, Robert PW, James RM. Maternal Vitamin D deficiency increases the risk of preeclampsia. J Clin Endocrinol Metab. 2007;92:3517-22.

33. Zeghoud F, Vervel C, Guillozo H, Walrant Debray O, Boutignon H, Garabedian M. Subclinical Vitamin D deficiency in neonates: definition and response to vitamin D suppliments. Am J Clin Nutr. 1997;65:771-8.

34. Maghbooli Z, Hossein NA, Karini F, Shafaei AR, Larijani B. Correlation between vitamin D3 deficiency and insulin resistance in pregnancy. Diabetes metab Res Rev. 2008;24:27-32.

35. Ferrant HJ, Krishnaveni GV, HillJC. Vit D insufficiency is common in Indian mothers but is not associated with gestational diabetes or variation in newborn size. Eur J Clin Nutr. 2009;63:646-52.

36. Tsur A, Feldman BS, Feldhammer I, Hoshen MB, Leibowitz G, Balicer RD. Decreased serum concentrations of 25 hydroxycholecalciferol are associated with increased risk of progression to impaired fasting glucose and diabetes. Dia care. 2013;36:1361-7.

37. McGrath J. Does imprinting with low prenatal vitamin $\mathrm{D}$ contribute to the risk of various adult disorders? Med hypothesis. 2001;56:367-71.

Cite this article as: Kumari A, Mitra S, Tiwari HC, Srivastav R. Hypovitaminosis D in pregnancy and its correlation with preeclampsia and gestational diabetes mellitus. Int J Reprod Contracept Obstet Gynecol 2017;6:890-6. 